\title{
PENGARUH KUALITAS PELAYANAN, CITRA MEREK DAN KEPUAS AN PELANGGAN TERHADAP LOYALITAS PELANGGAN LOGIS TIK PADA PT. TIKI JALUR NUGRAHA EKAKURIR (JNE) DI KOTA GRESIK
}

\section{RETNO AYU MAULFI}

Progam Studi Manajemen

Fakultas Ekonomi- Universitas Muhammadiyah Gresik

Jl. Sumatra No. 101 GKB Gresik 61121 Jawa Timur Indonesia

\begin{abstract}
ABSTRAK
Penelitian ini bertujuan melakukan pengujian pengaruh Kualitas Pelayanan, Citra Merek Dan Kepuasan Pelanggan Terhadap Loyalitas Pelanggan Logistik Pada PT. Tiki Jalur Nugraha Ekakurir (JNE) di Kota Gresik. Kemudian dilakukan tinjauan pustaka dan penyusunan hipotesis, data juga diperoleh dari penyebaran kuesioner terhadap 96 masyarakat Gresik yang pernah memakai jasa pengiriman barang PT. Tiki Jalur Nugraha Ekakurir (JNE) dengan menggunakan teknik nonprobability sampling. Pengujian dilakukan dengan menggunakan regresi linier berganda. Hasil analisis memperlihatkan bahwa kualitas pelayanan secara signifikan berpengaruh terhadap loyalitas pelanggan, citra merek secara signifikan berpengaruh terhadap loyalitas pelanggan dan kepuasan pelanggan secara signifikan berpengaruh terhadap loyalitas pelanggan.
\end{abstract}

Kata kunci : Kualitas Pelayanan, Citra Merek, Kepuasan Pelanggan, Loyalitas Pelanggan

\section{PENDAHULUAN}

Pada perkembangan saat ini, banyak bermunculan bisnis jasa pengiriman barang di Indonesia. Terdapat dua jenis perusahaan yaitu BUMN dan Swasta dalam menjalankan bisnis pengiriman barang. BUMN mempunyai Pos Indonesia sedangkan Swasta mempunyai JNE (Jalur Nugraha Ekakurir), TIKI (Titipan Kilat), DHLexpress (Dalsey, Hillblom dan Lynn), dan lainnya. Hal tersebut dilatar belakangi oleh UU No 38 tahun 2009 pasal 4 menyatakan bahwa perusahaan yang dapat masuk dalam usaha jasa di bidang kurir menjadi luas, tidak hanya terbatas pada Badan Usaha Milik Negara (BUMN), melainkan Badan Usaha Milik Daerah (BUMD) ataupun koperasi dan swasta bisa masuk ke dalam jasa kurir. Dengan munculnya peraturan tersebut, persaingan di bisnis kurir semakin kompetitif dikarenakan segala bentuk badan usaha dan swasta bisa masuk ke bisnis kurir tanpa pembatasan.

Obyek yang diambil peneliti dalam penelitian ini adalah PT. TIKI Jalur Nugraha Ekakurir (JNE) Gresik. Pasar e- commerce di Gresik di dominasi oleh bisnis pengiriman JNE. Hampir $70 \%$ pengiriman JNE Sub Agen Gresik adalah online shop, hal ini disebabkan karena perkembangan bisnis online di Kabupaten Gresik telah mencapai lebih dari $50 \%$ dibandingkan tahun sebelumnya (Sumber :http://radarsurabaya.jawapos.com pada tanggal 23 November 2016 penulis Firman Syah). Perusahaan JNE yang bergerak dibidang jasa kurir memiliki nama yang cukup terkenal dimata masyarakat, namun pada kenyataannya masih terdapat masalah tentang kualitas pelayanan yang belum memuaskan konsumen.

Hal ini ditimbulkan dari kualitas pelayanan yang masih harus diperbaiki dan harus menjadikan suatu perhatian penting bagi pihak manajemen JNE. Beberapa keluhan pelanggan akan kualitas pelayanan JNE (Su mber: PT JNE Sub Gresik 2016):

1. Paket yang dikirim tidak tepat waktu.

2. Pengembalian paket yang tidak terkirim karena alamatnya tidak jelas dan diinformasikan kepada pengirim dalam waktu yang lama.

3. Paket yang jatuh pada saat perjalanan sehingga sampai dipenerima rusak.

4. Karyawan yang melayani pelanggan dalam proses pelayanan yang lama.

Keluhan Pelanggan menurut Kotler dan Keller (2009:143) memperlihatkan bahwa jika pelanggan yang tidak puas dengan pembelian mereka berkisar $25 \%$, hanya sekitar $5 \%$ yang mengajukan keluahan. 95\% lainnya merasa bahwa menyampaikan keluhan tidak sebanding dengan usahanya atau mereka tidak tahu atau kepada siapa mereka akan menyampaikan keluhan itu dan mereka berhenti membeli. Dari pelanggan yang menyampaikan keluhan, antara $54 \%$ dan $74 \%$ akan membeli kembali ke perusahaan jika keluhan mereka diselesaikan. Angka itu akan naik menjadi 95\% jika pelanggan merasa keluahan mereka diselesaikan dengan cepat. 
Menurut Kotler dan Keller (2009:138) mendefinisikan loyalitas (loyalty) sebagai komitmen yang dipegang secara mendalam untuk membeli atau mendukung kembali produk atau jasa yang disukai di masa depan meski pengaruh situasi dan usaha pemasaran berpotensi menyebabkan pelanggan beralih. Hal ini menunjukkan bahwa loyalitas pelanggan merupakan komitmen pelanggan untuk menggunakan produk atau jasa pilihan dengan tingkat konsistensi yang tinggi.Loyalitas pelanggan tidak terjadi tanpa sebab, banyak sebab yang membuat pelanggan menjadi loyal seperti kepuasan pelanggan, pelayanan yang baik serta citra merek perusahaan.

Menurut Lovelock (2011:91) Pelanggan yang sangat puas atau bahkan menyenangi layanan cenderung menjadi pendukung loyal perusahaan, menggabungkan semua pembelian mereka dengan satu penyedia layanan dan menyebarkan berita positif. Menurut Lovelock dalam Tjiptono (2014:268) kualitas pelayanan adalah tingkat keunggulan (excellence) yang diharapkan dan pengendalian atas tingkat keunggulan tersebut untuk memenuhi keinginan pelanggan. Oleh sebab itu, apabila JNE ingin tetap unggul dalam persaingan, maka harus dapat memberikan jasa dengan kualitas yang lebih tinggi dari para pesaingnya secara konsisten. Kualitas pelayanan akan dapat mempengaruhi loyalitas pelanggan jika, JNE memiliki bukti langsung (fasilitas fisik yaitu ruangan front office, kebersihan dan penampilan karyawan), kehandalan, daya tanggap, jaminan, dan empati.

Menurut Kotler (2009: 403), citra merek adalah penglihatan dan kepercayaan yang terpendam di benak konsumen, sebagai cerminan asosiasi yang tertahan di ingatan konsumen. JNE telah membangun citra merek yang kuat dimata konsumen. Dimana JNE merupakan jasa pengiriman barang yang me mperoleh peringkat pertama pada du \a tahun terakhir ini. Semakin kuat citra merek yang dimiliki maka suatu merek dapat mengarahkan pada loyalitas konsumen terhadap suatu merek. Citra merek akan dapat mempengaruhi loyalitas konsumen jika, citra merek JNE memiliki kekuatan,keunikan dan keunggulan. Citra merek yang berbeda dan unik dapat mencipakan differensiasi dengan para pesaing.

Selain kekuatan dari citra merek, kepuasan pelanggan merupakan aspek yang sangat penting untuk mempertahankan bisnis dan memenangkan persaingan dengan perusahaan lain. Kepuasaan pelanggan adalah tingkat perasaan seseorang setelah membandingkan kinerja atau hasil yang ia rasakan dibandingkan dengan harapannya (Tjiptono 2014:354). Bila konsumen merasa puas akan jasa yang telah dikonsumsinya, besar kemungkinan dimasa yang akan datang orang tersebut akan melakukan pembelian ulang.

\section{Kualitas Pelayanan}

Menurut Tjiptono (2014: 268) Defin isi dari kualitas jasa atau pelayanan merupakan tingkat keunggulan (excellence) yang diharapkan dan pengendalian atas keunggulan tersebut untuk memenuhi keinginan pelanggan. Kualitas pelayanan yang baik dapat dicapai dengan memb ina hubungan yang erat antar perusahaan, dalam hal ini adalah karyawan dengan pengguna jasa tersebut. Dengan demikian maka kualitas merupakan faktor kunci sukses bagi suatu organisasi atau perusahaan (Laksana 2008:88)

Menurut Tjiptono (2014:282) bahwa terdapat lima dimensi yang dipakai untuk mengukur kualitas pelayanan, yaitu:

1. Bukti fisik (tangib les)

Bukti fisik (tangibles) yaitu kemampuan suatu perusahaan dalam menunjukkan eksistensinya kepada pihak eksternal.

2. Kehandalan (re liability)

Kehandalan (reliability) yaitu kemampuan perusahaan untuk memberikan pelayanan sesuai yang dijanjikan dengan segera, akurat dan me muaskan.

3. Daya tanggap (responsiveness)

Daya tanggap (responsiveness) yaitu keinginan para staf untuk membantu para pelanggan dan memberikan layanan dengan tanggap (responsif)

4. Jaminan (assurance)

Jaminan (assurance) yaitu pengetahuan, kesopansantunan, dan kemampuan para pegawai perusahaan untuk menumbuhkan rasa percaya para pelanggan kepada perusahaan.

5. Empati (emphaty)

Empati (emphaty) yaitu memberikan perhatian yang tulus dan bersifat individual atau pribadi yang diberikan kepada para pelanggan dengan berupaya memah ami keinginan konsumen.

\section{Citra Merek}

Menurut Kotler dan Keller (2009:403) citra merek ialah persepsi dan keyakinan yang dilakukan oleh konsumen, seperti yang tercermin dalam asosiasi yang terjadi dalam memori konsumen.

Berdasarkan pengertian citra merek diatas, maka dapat disimpulkan bahwa citra merek terbentuk dari persepsi yang telah lama terdapat di pikiran konsumen. Menurut Kotler dan Keller (2008:56) bahwa mengukur citra merek dapat dilakukan berdasarkan aspek sebuah merek yaitu : 


\section{Kekuatan (Strength)}

Dalam hal ini adalah keunggulan yang dimiliki oleh merek yang bersifat fisik dan tidak ditemukan oleh merek lainnya.

2. Keunikan (Un iqueness)

Keunikan merek adalah kemampuan untuk membedakan sebuah merek dengan merek lainnya.

3. Keunggulan (Favourable)

Yang termasuk dalam ke lompok favourable ini antara lain, kemudahan merek produk diucapkan serta kemampuan merek untuk tetap diingat oleh pelanggan yang membuat jasa terkenal dan men jadi favorit di masyarakat.

\section{Kepuasan Pelanggan}

Menurut Tjiptono 2014:353 berpendapat bahwa kepuasan pelanggan adalah respon emosional terhadap pengalaman- pengalaman yang berkaitan dengan produk atau jasa tertentu yang dibeli, gerai ritel, atau bahkan pola prilaku (seperti perilaku berbelanja dan perilaku pembeli), serta pasar secara keseluruhan.

\section{Loyalitas Pelanggan}

Menurut Kotler dan Keller (2009:138) mendefinisikan loyalitas (loyalty) sebagai komitmen yang dipegang secara mendalam untuk membeli atau mendukung kembali produk atau jasa yang disukai di masa depan meski pengaruh situasi dan usaha pemasaran berpotensi menyebabkan pelanggan beralih. Menurur Griffin 2009:31 pelanggan yang loyal adalah pelanggan yang memiliki karakteristik sebagai berikut :

1. Melakukan pembelian u lang secara teratur Loyalitas lebih mengacu pada wujud perlilaku dari unit-unit pengambilan keputusan untuk melakukan pembelian secara terus menerus terhadap barang atau jasa suatu perusahaan yang terpilih. Tingkat kepuasan terhadap toko akan mempengaruhi mereka untuk membeli ke mbali.

2. Membeli diluar lini jasa

Membeli diluar lini jasa artinya keinginan untuk membeli lebih dari jasa yang telah ditawarkan oleh perusahaan. Pelanggan yang sudah percaya pada perusahaan dalam suatu urusan, maka akan percaya juga untuk urusan lainnya.

3. Mereferensi toko kepada orang lain,artinya menarik pelanggan baru untuk perusahaan.

\section{Hipotesis}

Adapun hipotesis yang diajukan dalam penelitian ini adalah
H1 : Diduga Kualitas pelayanan berpengaruh terhadap loyalitas pelanggan di PT. TIKI Jalur Nugraha Ekakurir (JNE)

H2 : Diduga Citra Merek berpengaruh terhadap loyalitas pelanggan di PT. TIKI Jalur Nugraha Ekakurir (JNE)

H3 : Diduga Kepuasan pelanggan berpengaruh terhadap loyalitas pelanggan di PT. TIKI Jalur Nugraha Ekakurir (JNE)

H4 : Diduga Kualitas pelayanan, citra merek, dan kepuasan pelanggan berpengaruh secara simutan terhadap loyalitas pelanggan di PT. TIKI Jalur Nugraha Ekakurir (JNE)

\section{METODOLOGI PEN ELITIAN}

Pendekatan yang digunakan dalam penelitian ini adalah kuantitatif karena penelitian ini menggunakan data yang terukur, menggunakan metode (alat uji) statistik untuk perhitungan data dan akan menghasilkan suatu kesimpulan. Penelitian kuantitatif merupakan data yang berbentuk angka, atau data kuantitatif yang diangkakan atau Skoring (Sugiyono 2015:23).

\section{Populasi dan Sample}

Populasi pada penelitian ini adalah seluruh pengguna jasa logistik JNE di kota Gresik. Karena ju mlahnya sangat banyak (tersebar dan sulit diketahui secara pasti), maka dilakukan pengambilan sampel untuk penelitian ini. Pada penelitian ini metode pengambilan sampel yang digunakan adalah metode Nonprobability Sampling dengan teknik penggambilan sampel yang Purposive Sampling yaitu tehnik penentuan sampel dengan menggunakan pertimbangan tertentu (Sugiyono 2015:67). Pertimbangan tersebut ialah pelanggan JNE yang pernah menggunakan pelayanan JNE di Gresik lebih dari 1 (satu) kali.

\section{Uji Instrumen Uji Vali ditas}

Uji Validitas dilakukan untuk mengukur keabsahaan (Validitas) suatu kuesioer. Suatu kuesioner dinyatakan valid jika pertanyaan pada kuesioner mampu mengungkapkan sesuatu yang akan diukur kuesioner tersebut (Ghozali, 2009:15). Uji valid itas ini dapat juga dilakukan dengan membandingkan nilai masing-masing item pertanyaan dengan nilai total. Teknik ini dilakukan dengan membandingkan $r$ hitung dengan $r$ tabel. Apabila $\mathrm{r}$ hitung $>\mathrm{r}$ tabel, maka butir pertanyaan atau indikator variabel yang digunakan penelitian ini dianggap valid atau sah. Apabila $r$ hitung $<r$ tabel, maka dapat dikatakan item kuesioner tidak valid. 


\section{Uji Reliabilitas}

Uji reliabilitas merupakan uji kehandalan yang bertujuan untuk mengetahui seberapa jauh alat ujur tersebut dapat dipercaya. Suatu kuesioner dikatakan reliabel atau handal jika jawaban seseorang terhadap pertanyaan adalah konsisten atau stabil dari waktu ke waktu. Suatu data dikatakan reliabel adalah jika variabelnya memiliki nilai Cronbach alpha (a) lebih besar dari 0,6 (Ghozali, 2009:16).

\section{Uji Asumsi Klasik \\ Uji Normalitas}

Pengujian distribusi normal berfungsi untuk melihat apakah sampel yang diambil mewakili distribusi populasi. Jika distribusi sampel adalah normal, maka dapat dikatakan sampel yang diambil mewakili populasi (Imam 2016:92). Uji normalitas bertujuan untuk menguji apakah dalam model regresi, variabel terikat dan variabel bebas keduanya mempunyai distribusi normal ataukah tidak. Model regresi yang baik adalah memiliki distribusi data normal atau mendekati normal. Pada prinsipnya normalitas dapat dideteksi dengan melihat penyebaran data (titik) pada sumbu diagonal dari grafik atau histogram residual (Gho zali, 2009:74).

\section{Uji Multikolinearitas}

Uji mu ltikolinearitas bertujuan untuk menguji apakah dalam model regresi ditemu kan adanya korelasi antar variabel bebas (independen). Model regresi yang baik seharusnya tidak terjadi korelasi diantara variabel bebas. Multikoleniaritas dapat juga dilihat dari nilai tolerance dan Value Inflation Factor (VIF). Nilai toleransi yang rendah sama dengan nilai VIF yang tinggi. Jika nilai tolerance $>0,10$ dan nilai VIF < 10, maka dapat diartikan bahwa tidak terjadi multikoleniaritas pada penelitian tersebut.

\section{Uji Heterokedastisitas}

Heterokedastisitas artinya varians variabel dalam model tidak sama. Uji heteroskedastisitas bertujuan untuk menguji apakahpada model regresi terjadi ketidaksamaan variance dari residual suatu pengamatan ke pengamatan lain. Model regresi yang baik adalah tidak terjadi heteroskedastisitas. Jika tidak ada pola yang jelas, serta titik-titik menyebar di atas dan di bawah angka 0 pada sumbu $\mathrm{Y}$, maka tidak terjadi Heteroskedastisitas.

\section{Uji Autokorelasi}

Uji autokorelasi bertujuan menguji apakah dalam model regresi linear ada korelasi antara kesalahan pengganggu pada periode $t$ dengan kesalahan pengganggu pada periode t-1 (sebelumnya). Jika terjadi korelasi, maka dinamakan ada problem autokore lasi.

Autokorelasi muncul karena observasi yang berurutan sepanjang waktu berkaitan satu sama lainnya. Masalah ini timbul karena residual (kesalahan pengganggu) tidak bebas dari satu observasi ke observasi lainnya (Ghozali, 2009: 93). Uji autokorelasi dilakukan dengan metode Durbin-Watson. Jika nilai Durbin-Watson berkisar antara nilai batas atas (du) maka diperkirakan tidak terjadi autokore lasi.

\section{Uji Hipotesis}

\section{Uji t (Pengujian secara parsial)}

Untuk mengetahui apakah variabel independen secara parsial (individual) mempunyai pengaruh yang signifikan terhadap variabel dependen. Uji statistik $t$ pada dasarnya menunjukkan seberapa jauh pengaruh satu variabel independen secara individu dalam menerangkan variabel dependen (Ghozali 2009:88).

1. Kriteria dalam uji t dapat dilihat sebagai berikut :

a. $\quad \mathrm{H} 0=\mathrm{b} 1, \mathrm{~b} 2, \mathrm{~b} 3=0$ artinya variabel kualitas pelayanan (X1), citra merek (X2) dan kepuasan pelanggan (X3) secara parsial tidak berpengaruh terhadap loyalitas pelanggan (Y).

b. $\mathrm{H} 1=\mathrm{b} 1, \mathrm{~b} 2, \mathrm{~b} 3 \neq 0$ artinya variabel kualitas pelayanan (X1), citra merek (X2) dan kepuasan pelanggan (X3) secara parsial berpengaruh terhadap loyalitas pelanggan ( $\mathrm{Y}$ ).

2. Uji hipotesis dengan membandingkan $t$ hitung dengan $t$ table

1. Apabila $\mathrm{t}$ hitung $>\mathrm{t}$ tabel, maka $\mathrm{HO}$ ditolak dan H1 diterima. Artinya variabel kualitas pelayanan, citra merek dan kepuasan pelanggan secara parsial berpengaruh terhadap loyalitas pelanggan.

2. Apabila $\mathrm{t}$ hitung $<\mathrm{t}$ tabel, maka $\mathrm{H} 0$ diterima dan $\mathrm{H} 1$ ditolak. Artinya variabel kualitas pelayanan, citra merek dan kepuasan pelanggan secara parsial tidak berpengaruh terhadap loyalitas pelanggan. Dengan tingkat signifkasi $95 \% \quad(a=5 \%)$ dengan nilai df (degree of freedom) n-k-1 (96-3-1)=92, maka dapat diketahui nilait tabel sebesar 1.985.

3. Uji hipotes is berdasarkan signifiansi :

a. Jika angka sig. > 0,05, maka H0 diterima

b. Jika angka sig. $<0,05$, maka $\mathrm{H} 0$ ditolak Untuk mengetahui variabel mana yang paling berpengaruh terhadap loyalitas pelanggan, yaitu 
dengan melihat nilai koefisien beta dari masing-masing variabel.

\section{Uji F (Pengujian secara simultan)}

Uji statistik $F$ pada dasarnya menunjukkan apakah semua variabel independen atau bebas yang dimasukkan kedalam model mempunyai pengaruh secara bersama-sama terhadap variabel dependen atau terikat (Ghozali 2009:88).

1. Kriteria dalam uji F dapat dilihat sebagai berikut:

a. $\quad \mathrm{H} 0=\mathrm{b} 1, \mathrm{~b} 2, \mathrm{~b} 3=0$ art inya variabel kualitas pelayanan (X1), citra merek (X2) dan kepuasan pelanggan (X3) secara simultan tidak berpengaruh terhadap loyalitas pelanggan (Y).

b. $\mathrm{H} 1=\mathrm{b} 1, \mathrm{~b} 2, \mathrm{~b} 3 \neq 0$ art inya variabel kualitas pelayanan (X1), citra merek (X2) dan kepuasan pelanggan (X3) secara simultan berpengaruh terhadap loyalitas pelanggan (Y).

2. Uji hipotesis dengan membandingkan $\mathrm{F}$ hitung dengan $\mathrm{F}$ table

a. Apabila F hitung > F tabel, maka H0 ditolak dan $\mathrm{H} 1$ diterima. Artinya variabel kualitas pelayanan, citra merek dan kepuasan pelanggan secara simultan berpengaruh terhadap loyalitas pelanggan.

b. Apabila F hitung < F tabel, maka H0 diterima dan $\mathrm{H} 1$ ditolak. Artinya variabel kualitas pelayanan, citra merek dan kepuasan pelanggan secara simultan tidak berpengaruh terhadap loyalitas pelanggan.

3. Uji hipotesis berdasarkan signifiansi :

a. Jika angka sig. > 0,05, maka $\mathrm{H} 0$ diterima

b. Jika angka sig. < 0,05, maka H0 ditolak

\section{Koefisien deteminasi (R2)}

Koefisien determinasi digunakan untuk menjelaskan proporsi variabel bebas dalam menjelaskan variabel terikat. Nilai koefisien determinasi ada diantara 0 dan 1 . Nilai koefisien determinasi yang kecil berarti harga variabel bebasnya dalam menjelaskan variabel terikatnya sangat terbatas. Nilai yang mendekati satu berarti variabel bebas memberikan hampir semua informasi yang dibutuhkan untuk memprediksi variabel terikatnya.

\section{HAS IL DAN PEMBAHASAN \\ Uji Vali ditas}

Uji Validitas digunakan untuk menguji sejauh mana ketepatan alat pengukuran dapat mengugkapkan konsep atau gejala yang diukur. Dari tabel 4.10 menunjukkan seluruh butir pertanyaan dari variabel independen maupun dependen terbukti valid.

\section{Uji Reliabilitas}

Uji reliabilitas merupakan uji kehandalan yang bertujuan untuk mengetahui seberapa jauh alat ujur tersebut dapat dipercaya. Suatu data dikatakan reliabel adalah jika variabelnya memiliki nilai Cronbach alpha (a) lebih besar dari 0,6 (Ghozali, 2009:16). Berdasarkan tabel 4.11 menunjukkan bahwa variabel bebas dan variabel terikat mempunyai nilai alpha positif dan lebih besar dari nilai Cronbach alpha (a) yaitu 0,6 . Jadi item-ite m pertanyaan seluruhnya dianggap reliabel atau handal dalam me laku kan fungsinya sebagai alat ukur.

\section{Uji Normalitas}

Pengujian distribusi normal berfungsi untuk melihat apakah sampel yang diambil mewakili distribusi populasi. Jika distribusi sampel adalah normal, maka dapat dikatakan sampel yang diambil mewakili populasi (Imam 2016:92). Untuk mengetahui apakah suatu data terdistribusi secara normal atau tidak, dapat dilakukan dengan analisa grafik dengan melihat normal probability plot dan histogram.

\section{Analisis Linear Berganda}

Analisis regresi linier berganda digunakan untuk mengetahui pengaruh variabel bebas (X) terhadap variabel terikat (Y). Variabel bebas pada penelitian ini yaitu Kualitas pelayanan X1, Citra Merek X2, dan Kepuasan Pelanggan X3, sebagai variabel terikatnya yaitu loyalitas pelanggan pada PT JNE maka peneliti menggunakan regresi linier berganda dan pengolahannya dilakukan dengan menggunakan program SPSS for Windows dan didapatkan hasil sebagai berikut :

\section{$\mathrm{Y}=-1,568+0,227 \mathrm{X} 1+0,225 \mathrm{X} 2+0,348 \mathrm{X} 3$}

Dari persamaan regresi diatas, maka dapat dijelaskan sebagai berikut :

1. Nilai $\alpha=-1,568$ menunjukkan bahwa, jika variabel kualitas pelayanan (X1), Citra Merek (X2), dan Kepuasan Pelanggan (X3), bernilai 0, maka variabel loyalitas pelanggan $(\mathrm{Y})$ bernilai tetap yaitu $-1,568$ satuan.

2. Jika variabel kualitas pelayanan (X1) berubah dengan satu satuan nilai, maka loyalitas pelanggan (Y) akan berubah sebesar 0,227 satuan, dengan asumsi Citra Merek (X2), dan Kepuasan Pelanggan (X3) bersifat tetap.

3. Jika variabel citra merek (X2) berubah dengan satu satuan nilai, maka loyalitas 
pelanggan (Y) akan berubah sebesar 0,225 satuan, dengan asumsi Kualitas pelayanan (X1), dan Kepuasan Pelanggan (X3) bersifat tetap.

4. Jika variabel kepuasan pelanggan (X3)

berubah dengan satu satuan nilai, maka loyalitas pelanggan (Y) akan berubah sebesar 0,348 satuan, dengan asumsi Kualitas pelayanan (X1) dan Citra Merek (X2), bersifat tetap.

Tabel 4.2 Hasil Uji Regresi Linier Berganda Coefficientsa

\begin{tabular}{|c|c|c|c|c|c|c|c|}
\hline \multirow[t]{2}{*}{ Model } & \multicolumn{2}{|c|}{$\begin{array}{l}\text { Unstandardized } \\
\text { Coefficients }\end{array}$} & \multirow{2}{*}{\begin{tabular}{|l|}
$\begin{array}{l}\text { Standardized } \\
\text { Coefficients }\end{array}$ \\
Beta \\
\end{tabular}} & \multirow[t]{2}{*}{$\mathrm{T}$} & \multirow[t]{2}{*}{ Sig. } & \multicolumn{2}{|c|}{$\begin{array}{l}\text { Collinearit Statistics } \\
\text { y }\end{array}$} \\
\hline & B & Std. Error & & & & Tolerance & VIF \\
\hline $\begin{array}{l}\text { (Constant) } \\
\text { Kualitas Pelayanan } \\
\text { Citra Merek } \\
\text { Kepuasan Pelanggan }\end{array}$ & $\begin{array}{l}-1,568 \\
, 227 \\
225 \\
, 348\end{array}$ & $\begin{array}{l}1,545 \\
080 \\
081 \\
084\end{array}$ & $\begin{array}{l}, 253 \\
, 269 \\
, 370\end{array}$ & $\begin{array}{l}-1,015 \\
2,838 \\
2,793 \\
4,155\end{array}$ & $\begin{array}{l}, 313 \\
, 006 \\
, 006 \\
, 000\end{array}$ & $\begin{array}{l}, 571 \\
, 488 \\
, 570\end{array}$ & $\begin{array}{l}1,753 \\
2,048 \\
1,753\end{array}$ \\
\hline
\end{tabular}

a. Dependent Variable: Loyalitas Pelanggan

\section{Koefisien Determinasi R2}

Koefisien Determinasi ini digunakan untuk mengetahui seberapa besar pengaruh variabelvariabel bebas memiliki pengaruh terhadap variabel terikatnya.

Tabel 4.3 Hasil Koefisien Determinasi R2

\begin{tabular}{|l|l|l|l|}
\hline Model & $\mathrm{R}$ & R Square & $\begin{array}{l}\text { Adjusted R } \\
\text { Square }\end{array}$ \\
\hline 1 &, $764 \mathrm{a}$ &, 584 &, 570 \\
\hline
\end{tabular}

1. Adjusted R Square sebesar 0,570 dapat dikatakan bahwa perubahan variabel dependen loyalitas pelanggan (Y) sebesar $57 \%$ mampu menjelaskan terhadap variabel kualitas pelayanan (X1), citra merek (X2), kepuasan pelanggan (X3), sedangkan sisanya sebesar $43 \%$ disebabkan oleh variabel lain yang tidak diteliti.

2. R Square 0,584 artinya proporsi variasi dalam variabel bebas kualitas pelayanan (X1), citra merek (X2), kepuasan pelanggan (X3) mampu menjelaskan variabel terikat keputusan (Y) sebesar $58,4 \%$ selebihnya $41,6 \%$ disebabkan oleh variabel lain yang tidak dite liti.

3. $\mathrm{R}=0,764$ artinya kuatnya hubungan antar variabel idependen (X) bersama sama terhadap variabel dependen (Y) yaitu $76,4 \%$

\section{Uji Hipotesis}

Uji $\mathbf{t}$

Pengaruh variabel Kualitas Pelayanan (X1) terhadap Loyalitas Pelanggan (Y) Berdasarkanhasil perhitungan, nilai $t$ hitung sebesar 2,838> nilai t tabel sebesar 1,985, maka H0 ditolak dan $\mathrm{H} 1$ diterima. Variabel kualitas pelayanan berpengaruh

signifikan terhadap loyalitas pelanggan karena nilai signifikansi $<0,05$ yaitu sebesar 0,006 . Dapat disimpulkan bahwa kualitas pelayanan berpengaruh secara parsial terhadap loyalitas pelanggan.

Pengaruh variabel Citra Merek (X2) terhadap Loyalitas Pelanggan (Y)

Berdasarkan hasil perhitungan,nilai t hitung sebesar 2,793> nilai t tabel sebesar 1,985, maka H0 ditolak dan H1 diterima. Variabel citra merek berpengaruh signifikan terhadap loyalitas pelanggan karena nilai signifikansi $<0,05$ yaitu sebesar 0,006.

Dapat disimpulkan bahwa citra merek berpengaruh secara parsial terhadap loyalitas pelanggan.

Pengaruh variabel Kepuasan Pelanggan (X3) terhadap Loyalitas Pelanggan (Y) Berdasarkan hasilperhitungan, nilai $t$ hitung sebesar 2,793> nilai t tabel sebesar 1,985, maka $\mathrm{H} 0$ ditolak dan $\mathrm{H} 1$ diterima. Variabel kepuasan pelanggan berpengaruh signifikan terhadap loyalitas pelanggan karena nilai signifikansi $<0,05$ yaitu sebesar 0,000 . Dapat disimpulkan bahwa citra merek berpengaruh secara parsial terhadap loyalitas pelanggan.

\section{Uji F (Simultan)}

Uji statistik F pada dasarnya menunjukkan apakah semua variabel independen atau bebas yang dimasukkan kedalam model mempunyai 
pengaruh secara bersama-sama terhadap variabel dependen atau terikat (Ghozali 2009:88).

Perumuasan hipotesisnya adalah sebagai berikut :

a. Apabila F hitung > F tabel, maka H0 ditolak dan $\mathrm{H} 1$ diterima.

b. Apabila $\mathrm{F}$ hitung < $\mathrm{F}$ tabel, maka $\mathrm{H} 0$ diterima dan $\mathrm{H} 1$ ditolak.

Tabel 4.4 Hasil Uji F ANOVAb

\begin{tabular}{|ll|l|l|l|l|}
\hline Model & $\begin{array}{l}\text { Sum of } \\
\text { Squares }\end{array}$ & df & $\begin{array}{l}\text { Mean } \\
\text { Square }\end{array}$ & F \\
\hline 1 & $\begin{array}{l}\text { Regression } \\
\text { Residual }\end{array}$ & 302,351 & 3 & 100,784 & 43,048 \\
& Total & 517,388 & 92 & 2,341 & \\
\hline
\end{tabular}

a. Predictors: (Constant), Kepuasan Pelanggan, Kualitas Pelayanan, Citra Mer

b. Dependent Variable: Loyalitas Pelanggan

Tingkat signifikansi $\quad 0,05 \%$ atau $5 \%$ dengan nilai df (degree of freedom) dengan df pembilang $=\mathrm{k}=3$ dan df penyebut $\mathrm{n}-\mathrm{k}-1=96-$ 3-1=92 Jadi $F$ tabel sebesar 2.70 dengan $F$ hitung yaitu 43,048 . Sehingga diketahui bahwa $\mathrm{F}$ hitung > F tabel. Berarti variabel kualitas pelayanan, citra merek dan kepuasan pelanggan, secara simultan berpengaruh teradap loyalitas pelanggan JNE di Kota Gresik.

\section{KES IMPULAN}

Setelah dilakukan pengujian pengaruh kualitas pelayanan, citra merek dan kepuasan pelanggan terhadap loyalitas pelanggan PT. TIKI Jalur Nugraha Ekakurir (JNE) di kota Gresik, maka dapat disimpulkan sebagai berikut :

1. Hasil penelitian variabel kualitas pelayanan $(\mathrm{X} 1)$ diperoleh $\mathrm{t}$ hitung $>\mathrm{t}$ tabel yaitu $2,838>1,985$ dan probabilitas (signifikansi) $0,006<0,05$, maka $\mathrm{H} 0$ ditolak dan $\mathrm{H} 1$ diterima. Berarti variabel kualitas pelayanan (X1) berpengaruh positif terhadap loyalitas pelanggan di PT. TIKI Jalur Nugraha Ekakurir (JNE) di Kota Gresik.

2. Hasil penelitian variabel citra merek (X2) diperoleh t hitung > t tabel yaitu 2,793 > 1,985 dan probabilitas (signifikansi) 0,006 $<0,05$, maka H0 ditolak dan H1 diterima. Berarti variabel citra merek (X2) berpengaruh positif terhadap loyalitas pelanggan di PT. TIKI Jalur Nugraha Ekakurir (JNE) di Kota Gresik.

3. Hasil penelitian variabel kepuasan pelanggan (X3) diperoleh $\mathrm{t}$ hitung $>\mathrm{t}$ tabel yaitu $4,155>1,985$ dan probabilitas (signifikansi) $0,000<0,05$, maka $\mathrm{H} 0$ ditolak dan $\mathrm{H} 1$ diterima. Berarti variabel kepuasan pelanggan (X3) berpengaruh positif terhadap loyalitas pelanggan di PT. TIKI Jalur Nugraha Ekakurir (JNE) di Kota Gresik.

4. Dari uji regresi diperoleh $F$ hitung $(43,048)>$ F tabel $(2,70)$ berarti Variabel Kualitas pelayanan, citra merek, dan kepuasan pelanggan secara simutan berpengaruh terhadap loyalitas pelanggan di PT. TIKI Jalur Nugraha Ekakurir (JNE) di Kota Gresik

\section{Saran}

Saran Manajemen JNE di Gresik berdasarkan kesimpulan tersebut, maka dibuat rekomendasi sebagai berikut :

1. PT. JNE harus memperhatikan klaim konsumen atas kesalahan yang sama untuk meningkatkan kualitas pelayanannya yaitu dengan melakukan pengawasan langsung pada saat proses pengiriman barang agar mengurangi dampak kerusakan, kehilangan, dan keterlambatan barang ke tujuan.

2. PT. JNE dapat melakukan kegiatan promosi bagi para konsumen yang loyal dalam menggunakan jasa pengiriman JNE. Promosi ini bisa berupa member card, dimana pelanggan akan mendapatkan point, diskon, atau hadiah tertentu jika memenuhi syarat dari pihak JNE.

\section{Saran bagi Peneliti selanjutnya}

Peneliti selanjutnya bisa melakukan penelitian ini dengan meneliti faktor lain yang dapat mempengaruhi loyalitas pelanggan, misalnya harga dan kepercayaan pelanggan. Peneliti selanjutnya juga dapat menggunakan metode lain dalam meneliti loyalitas pelanggan, misalnya melalui wawancara mendalam terhadap Responden sehingga informasi yang diperoleh dapat lebih bervariasi daripada angket yang jawabannya telah tersedia.

\section{DAFTAR PUS TAKA}

Arikunto,Suharsimi,2010, "Prosedur Penelitian Suatu Pendekatan Praktik”. Rineka Cipta, Yogyakarta.

Ferdinand,Augusty,2014, “Metode Penelitian Manajemen”, Badan Penerbit Universitas Diponegoro, Semarang.

Gozali,Imam,2009, "Aplikasi $\quad$ analisis
multivariat dengan program SPSS",
Badan penerbit
Diponegoro,Semarang.


Griffin, Jill, 2009, “Customer Loyalty, How to learn it, How to Keep it”,Erlangga, Jakarta.

Gunawan,Imam, 2016," Pengantar Statistika Inferensial ", Raja wali pers, Jakarta

Karundeng, Feibe Permatasari, 2013,"Kualitas Pelayanan Dan Kepuasan Pengaruhnya Terhadap Loyalitas Konsumen Pada Rumah Makan Mawar Sharron Wanea Manado", Jurnal Manajemen, Universitas Sam Ratulangi Manado.

Kotler,Philip dan Amstrong,Gary,2008, "Prinsip-prinsip Pemasaran",Jilid 1, Ed isi Dua belas,Erlangga,Jakarta.

Laksana, Fajar, 2008,"Manajemen Pemasaran", Ed isi 1, Graha ilmu, Yogyakarta.

Lovelock, Christoper, dkk , 2011, "Pemasaran Jasa”, Jilid 2, Edisi ketujuh,Erlangga,Jakarta.

Lupiyoadi,Rambat dan Hamdani,A, 2006, "Manajemen Pemasaran Jasa", Edisi 2, Salemba empat, Jakarta jasa dan Transportasi”, Raja Grafindo Persada,Jakarta.

Neria,Melka, 2012,"Pengaruh Citra Merek Terhadap Loyalitas Konsumen Maskapai Penerbangan Garuda Indonesia", Jurnal FISIP, Universitas Indonesia.

Pradipta,Dyah, 2012," Pengaruh Citra Merek (Brand Image) Terhadap Loyalitas Konsumen Produk Oli Pelumas Pt Pertamina (Persero) Enduro 4t di Makassar", Jurnal Manajemen,Universitas Hasanuddin Makas ar.

Rangkuti,Freddy, 2008,“Analysis SWOT Teknik membedah Kasus Bisnis", Gramed ia Pustaka Utama,Jakarta.

Santoso, Septiadi,2013, "Pengaruh Kualitas Pelayanan Terhadap Loyalitas Pelanggan Laboratorium Klinik Populer Surabaya”,Jurnal Ilmu dan Riset Manajemen,Sekolah Tinggi Ilmu Ekonomi Indonesia (STIESIA) Surabaya.

Sinaga, Alfi Ranita ,2016, "Pengaruh Kualitas Pelayanan Dan Citra Merek Terhadap Loyalitas Pelanggan (Studi Pelanggan KfC Metrocity Pekanbaru)",Jurnal Ilmu

Admin is trasi,Universitas Riau.
Syah, Muhammad Firman, 2016, 23 November, "Arus pengiriman barang melalui jasa kiriman logistik akhir tahun ini diperkirakan meningkat", tersedia:http://radarsurabaya.jawapos $\mathrm{com} / \mathrm{r} \quad$ ead/2016/11/23/4559/akh ir tahun- logistik-belanja-online-bakal naik/2

Tjiptono, Fandy, 2014,"Pemasaran Jasa Prinsip,Penerapan,dan Penelitian", ANDI, Yogyakarta.

Umar, Husein, 2010, "Riset pemasaran dan perilaku konsumen", cetakan ke 5, Gramed ia Pustaka,Jakarta.

Wijayanto, Tyas Catur, dkk, 2015, "Pengaruh Brand Image, Brand Reputation Dan Service Quality Terhadap Customer Loyalty Atas Produk Oli Endurodi Spbu Coco Penggaron Semarang”, Jurnal manajemen, Universitas Pandanaran Semarang. 